\title{
A STUDY ON QUALITY OF WORKLIFE AMONG PRIVATE HOSPITAL NURSES WITH REFERENCE TO VISAKHAPATNAM
}

\author{
Rajeswari Madey, Dr. S. Anitha Devi
}

Research Scholar, Acharya Nagarjuna University, Guntur, AP, India Associate Professor \& Head, Department of Management Studies, TJPS College, Guntur, AP, India

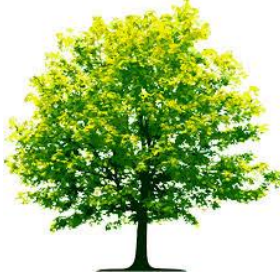

Keywords: Quality of Work Life; Private Hospitals; Nurses.

\begin{abstract}
A B S T R A C T
In the life of a working person, the caliber of work life holds prime importance. Over a period of time, numerous opportunities have been created in the corporate globe, each proposing a more conducive work environment for the employee than the terminal. This has given boost to employee expectations, which, coupled with the sufferance of the importance of employee retention, has driven employers to think even about the minutes of parameters which influence the character of workplace life. Quality of nursing care is seen as an important aspect in assessing the quality of wellness care. The caliber of nursing and health maintenance is directly interlinked to levels of job satisfaction among nurses and on the quality of nurse's work life. The quickly changing health care environment has had an impingement on the nursing work environment, workload and quality of nursing work life. In this paper studies the character of work life among private hospital nurses.
\end{abstract}

Citation: Md Sarafat \& Shamima Akter (2018). Life Satisfaction Of Elderly Aged People In Relation To Demographic Variable. International Journal of Advanced Multidisciplinary Scientific Research (IJAMSR) ISSN:2581-4281 Vol 1, Issue 7, September, 2018, \#Art.717, pp 69-75

\section{Introduction}

In the life of a working person, the caliber of work life holds prime importance. Over a period of time, numerous opportunities have been created in the corporate globe, each proposing a more conducive work environment for the employee than the terminal. This has given boost to employee expectations, which, coupled with the sufferance of the importance of employee retention, has driven employers to think even about the minutest of parameters which influence the character of workplace life. Though the character of work life has always been of paramount importance. For different industries, establishments and individuals there exist different set of genes, which influence the character of work life and in turn motivate or de motivate the employees. 


\section{International Journal of Advanced Multidisciplinary Scientific Research (IJAMSR) ISSN:2581-4281}

Quality of nursing care is seen as an important aspect in assessing the quality of wellness care. The caliber of nursing and health maintenance is directly interlinked to levels of job satisfaction among nurses and on the quality of nurse's work life. The quickly changing health care environment has had an impingement on the nursing work environment, workload and quality of nursing work life. Surveys have expressed that the workplace environment has an shock on the patient outcomes and nursing work life. Evidence demonstrates that nursing shortage, inadequate quality of nurse's work life, job dissatisfaction and poor patient outcomes are immediately related to lack of a healthy work environment.

\section{Importance of Nurses in the Society}

Nurses play a central role in handing over health care. Nurse's advocate for health promotion, educates patients and the public on the prevention of sickness and injury, provide attention and assist in curing, participate in rehabilitation, and offer reinforcement. No other health care professional such a full and far-reaching role. Nurses help families learn to become healthy by assisting them realize the range of emotional, physical, mental and cultural experiences they encounter during health and unwellness. Nurses help people and their families cope with illness, deal with it, and if necessary live with it, so that other sections of their lives can go forward. Nurses do more than charge for souls. They have always have been at the cutting edge of change in wellness care and public wellness. The nurse provides ongoing assessment of people's health. Their round-theclock presence, observation skills, and vigilance allow doctors to create better diagnoses and purpose better treatments. Many spirits have been laid aside because an attentive nurse picked up on early warning signs of an upcoming crisis like cardiac arrest or respiratory failure.

\section{Quality of Nursing Work Life}

Job satisfaction was the most commonly conducted research in breast feeding. Job satisfaction mainly focuses on the likes and the dislikes of the employees and little interest is applied to the work environment. Therefore problems related to the nursing work environment were not much spoken. Character of work life was the concept which gained much acceptance in nursing. Numerous surveys have been performed to assess the character of work life among nurses. Character of work life provided a diversity of definitions and predictors that influence the character of work life among nurses. But there was a lack of uniformity in findings related to quality of work life.

\section{Importance of Quality of Nursing Work Life}

According to Brooks, the land mark studies done in work environment, work place and job satisfaction could make drastic improvements in nursing profession related to turnover and shortage. The majority of subjects in nursing which evaluated job satisfaction was not capable to get to any lasting contributions in the nursing work environments. The profession still could not find appropriate explanations to the work life concerns of Clinical nurses.

Quality of Nursing Work Life is studied to be more efficient since it is grown specifically to judge the work life of nursing. The concept of Quality of Nursing Work Life which is specific to nursing profession provides relevant and valuable information regarding the character of work life among nurses. Brooks identified that no measures existed to assess the quality of nursing work life specifically. This interruption in the evidence 
compelled her to prepare an instrument in quality of nursing work life.

\section{Aim of the survey}

- To examine the character of work life of nurses going in private hospitals in Visakhapatnam.

- To examine the variables which determine the character of work life at work place for nannies.

- To distinguish the importance of work environment towards the performance of nurses.

- To know which draw out the nurses able to balance their study life with personal life.

- To know salary level, approach of superior workload, quality of work Environment.

\section{Scope and Significant of the Study}

Character of Work Life has come out as one of the most important aspects of job that insures long term association of employees with the system. It is indispensable for the organization to develop quality relation between its employees and working environment because now-a-days, demanding of a job creates imbalance between family and work life due to job pressure and conflicting interests.

Healthcare sector, being one of the largest service sector employers today is also not saved from the dreaded evil of 'attrition'. The employees have certain expectations from such institutions as well. And, if not fulfilled, new opportunities are there to poach away such talented employees. Hence, it is really important that the management of the healthcare institutions to tighten their seat belts and probe deeper to understand such areas which, when catered to will help in attracting fresh talent and keeping them. The present work deals with some important aspects of quality of work life among private hospital nurses.

\section{Strategic Collection of Data}

The data is collected through primary and secondary sources.

\section{Primary data sources}

Primary data was gathered from the respondents using structured questionnaires, which was set up in such a manner that, it enables the respondent to show their opinion freely and frankly and collect data from 150 respondents.

\section{Secondary data analysis}

Secondary data was compiled from different printed and unpublished research reports, textbooks, magazine, journals, articles, web site and so forth

\section{Tools of Analysis}

- Simple percentage analysis

- $\quad$-test

- ANOVA

- Garrett ranking technique

- Correlation 


\section{International Journal of Advanced Multidisciplinary Scientific Research (IJAMSR) ISSN:2581-4281}

\section{Limitations}

- $\quad$ Sample size is restricted to 150 nurses.

- In that location may be errors due to the prejudice of the answerers.

- Due to time restraints and busy schedule of nurses, it was difficult to interact with them altogether.

- The field is limited to nurses in Visakhapatnam.

There for the determinations of the survey cannot be expanded to other countries.

\section{A critical review of the literature}

S. Khodadadi et al (2014) investigated the QWL dimension effect on the employees' job satisfaction. In this study independent variables were permanent security, providing, salary and benefits payment policies, growth and advancement opportunity, and job independence, job satisfaction as the dependent variables. 114 employees selected randomly for this subject and two questionnaires of "quality of work life" and "job satisfaction" was utilized for data collection and Data analysis was done by using SPSS and LISREL software. He pounded out that the salary and benefits' policies have a significant and positive effect on Shuhstar's Shohola Hospital employees' job satisfaction.

Dr.O.P. Singh and Sandeep Kumar Singh, (2015) observed on quality of work life if teachers working in higher education institutions: A strategic approach towards teacher's excellence. He founded that quality of work life is an important issue from the teacher's position as it affect the job satisfaction level, commitment, execution and execution stage. He also indicates that higher educational authority should take progressive steps to organize a conductive and congenial work cultural and environment at higher education level in which every teacher goes in a clear manner for their own excellence and for institutional effectiveness as well.

\section{Inamual Haque, MD Suhail Rana and Zainal} Abedin (2015) stated on assessing the quality of work life of garment works in Bangladesh, a study on garment industries in Dhaka city. They pounded out that the quality of work life has a predominant role in the garment industry. He also hints that give importance to insure sound health and safety efforts of employers.

Dr Yogesh Jain and renil Thomas (2016) he studied on quality of work life among the employees of a leading pharmaceutical limited company of Vadodara district. He established that there exist a relationship between organizational commitment and other four components of quality of work life. He proposes that the society must organize the policy on career progression and career placement for better inflow of knowledge. He also suggests that society must do away the traditional method of gaining an employee purely on the basis of higher status even if the better talent on the basis of performance is available, as the company will begin facing the elevation of labor turnover problem at the earliest.

\section{Walton Model of Quality of Work Life}

The other approach to QWL is provided by Walton (1973). Walton proposes an ideal quality of work life programme which will include practices in eight major areas as discussed below: 


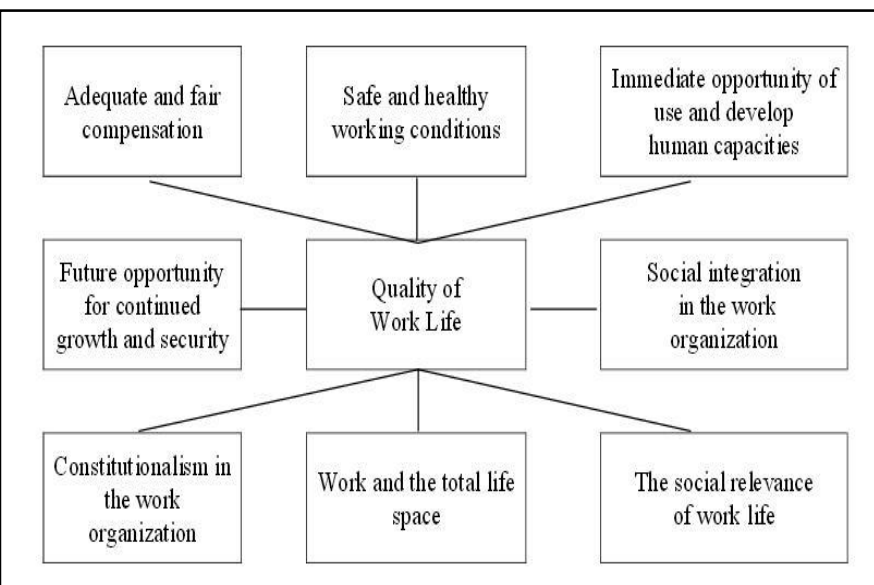

Walton Model of Quality of Work Life

Analysis and Interpretations

Board 1: showing the Level of Quality of Work Life

\begin{tabular}{|l|l|l|}
\hline $\begin{array}{l}\text { Great quality of work life } \\
\text { balance }\end{array}$ & Frequency & Percentage \\
\hline Low(17-42) & 44 & 29.3 \\
\hline Moderate(43-49) & 60 & 40.0 \\
\hline High (50-85) & & \\
\hline & 46 & 30.7 \\
\hline & 150 & 100.0 \\
\hline
\end{tabular}

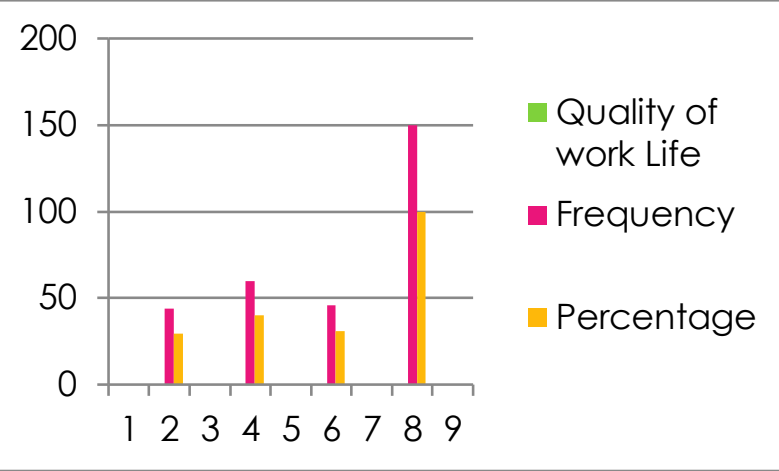

Chart 1: showing the Level of Quality of Work Life

\section{Interpretation}

It is found from the table that $29.3 \%$ of the respondents have low level of quality of work life, $40 \%$ of the respondents have moderate level of quality of work life and remaining $30.7 \%$ of the respondents have high level of quality of work life.

Table 2: showing correlation between stress and quality of work

\begin{tabular}{|l|l|l|l|}
\hline \multicolumn{2}{|l|}{ life Correlation } & & $\begin{array}{l}\text { Total Quality of } \\
\text { work life }\end{array}$ \\
\hline Stress level & Pearson correlation & 1 & .128 \\
\cline { 2 - 4 } & Sig.(2-tailed) & & .117 \\
\cline { 2 - 4 } & & $\mathrm{N}$ & \\
\hline \multirow{2}{*}{\begin{tabular}{c} 
Total Quality Work life \\
\cline { 2 - 4 }
\end{tabular}} & Pearson correlation & .128 & 1 \\
\hline & & 150 & 150 \\
\cline { 2 - 4 } & Sig.(2-tailed) & .117 & \\
\cline { 2 - 4 } & $\mathrm{N}$ & 150 & 150 \\
\hline
\end{tabular}




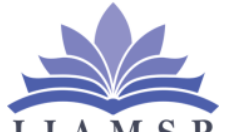

International Journal of Advanced Multidisciplinary Scientific Research (IJAMSR) ISSN:2581-4281

\section{Interpretation}

To recover out the relationship between the degree of stress and Quality of Work Life correlation was performed. The $\mathrm{p}$ value (. 117) is greater than.05 then there is no significant relationship between tension and quality of workplace life.

\section{Determinations}

- $\quad$ The bulk of the respondents are facing high levels of tension

- A majority of $40 \%$ of the respondents have moderate level of quality of work life.

- $\quad$ Ranking of major motivational factors salary is placed first, convenient shift is ranked second, good working status is placed third, business security is ranked fourth and other incentives are ranked fifth.

- The p value (.000) is less than. 05. Thus there is a significant mean difference in the character of work life based on the gender of the answerer.

- The p value (.000) is less than. 05. Thus there is a significant mean difference in the character of work life based on marital status of the answerer.

\section{Suggestions}

- The system can provide regular medical checkup for improving the medical facilities.

- The system can provide efficient training for effective functioning of employees.

- The system can improve promotional policies

- $\quad$ Provide substantial freedom, independence and discretion to employees in scheduling their work.
- Team culture, peer relations also influence the caliber of work life of the employees. And then on that point should be good relationship between employees.

\section{Conclusion}

The work was performed to ascertain the quality of nursing work life among nurses working in Visakhapatnam. The survey findings revealed that in that location was a restrained character of nursing work life reported among nurses in the private sector. The employment environment of the nurses was given less importance and they were compelled to make do with limited imaginations. Even though the nurses in the private sector reported lesser work load, they were more dissatisfied with the salary and financial benefits. The wage in the private sector was significantly more depressed. 


\section{International Journal of \\ I J A M S R Advanced Multidisciplinary Scientific Research (IJAMSR) ISSN:2581-4281}

References:

[1] Ayesha et al (2012), an evaluation of the quality of work life among male and female employees of private bank in Bangladesh, Int. Journal of Economics and Management 5(1)

[2] D. Chitraa, V. Mahalakshmi (2012), a Panimalar Engineering College, Chennai, India: A Study on Employees' Perception on Quality of Work Life and Job Satisfaction in manufacturing organization - an Empirical study, International Journal of Trade and Commerce-IIARTC, 1 (2).

[3] ChandranshuSinha (2012)factors affecting quality of work life :empirical evidence from Indian Organisation

[4] SeemaArif S., \& Ilyas M., (2013). Quality of Worklife model for Teachers of Private Universities in Pakistan. Quality Assurance in Education, Emerald Group Publishing Limited. 21(3), 282-298

[5] G.S. sandhyanair (2013), a study on the effect of quality of work life on organisational citizenship behaviour - with special reference to college teachers is thrissur district, kerala,journal of basic and applied scientific research, vol 2(9).

[6] AnandPawar,(2013),quality work-life and job satisfaction of employees in VTPS International journal of management research and review, March, Volume 3/Issue 3/Article No-7/2547-2556

[7] K. R.Nia\& Maryam Maleki (2013), A study on the relationship between quality of work life and organizational commitment of faculty members at Islamic Azad University, International Journal of Research in Organizational Behavior and Human Resource Management, Vol. 1, No. 4,

[8] H. Mohammadia\& M. A. Shahrabib (2013),A study on relationship between quality of work life and job satisfaction an empirical investigation, management science letter, 2 .

[9] Z. Amin (2013), A study on the Quality of Work Life in Indonesian Public Service Organizations to predict the role of Career Development and Personal Factor, International Journal of Applied

[10] S. Khodadadi et al (2014) investigating the $Q W L$ dimensions effect on the employees' job satisfaction, Applied mathematics in Engineering, Management and Technology, 2 (1.

[11] Dr.O.P. Singh and Sandeep kumar singh, (2015) on quality of work life if teachers working in higher educational institution: A strategic approach towards teacher's excellence. International Journal of Advances research in computer science and management studies Vol 3 Issue 9.

[12] MD.Inamual Haque, MD Suhail Rana and Zainal abedin (2015) Assessing the quality of work life of garment works in Bangladesh, a study on garment industries in Dhaka city. Global Journal of Management and business research, E-Marketing VOl-15 issue 3 Version 1.0.
[13] Dr yogesh jain and renil Thomas(2016) on quality of work life among the employees of a leading pharmaceutical limited company of Vadodara district. International journal of applied research impact factor 5.2. 